
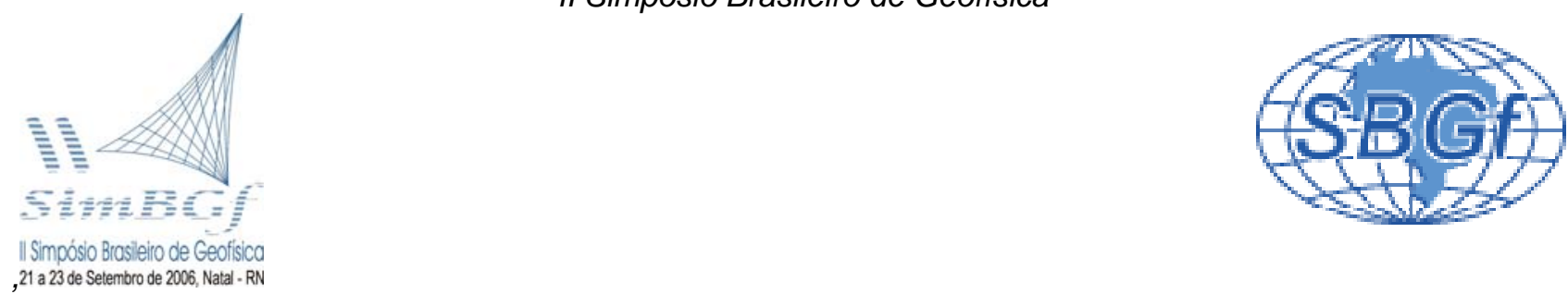

\title{
Geotectonic studies in the Brazilian territory: past, present and future
}

\author{
Jesus Berrocal ${ }^{1}$, Marcelo Assumpção ${ }^{1}$, Reinhardt Fuck ${ }^{2}$, José Eduardo Pereira Soares ${ }^{2}$ \& Fábio André Perosi ${ }^{1}$ \\ (1) Instituto de Astronomia, Geofísica e Ciências Atmosféricas, Universidade de São Paulo \\ ${ }^{(2)}$ Instituto de Geociências, Universidade de Brasília, CEP 70910-900, Brasília DF, Brazil)
}

\section{Copyright 2006, SBGf - Sociedade Brasileira de Geofísica}

Este texto foi preparado para a apresentação no Il Simpósio de Geofísica da Sociedade Brasileira de Geofísica, Natal, 21-23 de setembro de 2006. Seu conteúdo foi revisado pela Comissão Tecno-científica do II SR-SBGf mas não necessariamente representa a opinião da SBGf ou de seus associados. E proibida a reprodução total ou parcial deste material para propósitos comerciais sem prévia autorização da SBG

\section{Abstract}

Most of South American continental territory is lacking of geotectonic studies for determining the crust and upper mantle structure. Modern seismological broadband methods and deep seismic profiling with refraction and reflection experiments carried out in North America and Europe, permitted to trace down major geological features to the lower crust; some of them rooting into the upper mantle, unveiling fossil subduction zones; and also, previously unsuspected crustal boundaries have been recognized. A pioneer geotectonic study performed in the Tocantins Province, contributed decisively to the understanding of the deep structure of Central Brazil and shed new light on the evolution of the Brasilia Belt and adjoining blocks. New geotectonic project in Brazil, like the one at Borborema Province, will be discussed.

\section{Introduction}

Systematic exploration of continental lithosphere over the past decades by seismic reflection and refraction, as well as up-to-date seismological methods, has revolutionized our view of the deep crust and upper mantle. From these studies, major geological features have been traced down to the lower crust; some of them rooting into the upper mantle, unveiling fossil subduction zones. Some geotectonic boundaries, considered by generations of geologists to be major crustal sutures, have shown to be splays off underlying lithospheric boundaries instead. On the other hand, previously unsuspected crustal boundaries have been recognized, and in some cases mountain chains, which previously thought to be rooted into the mantle were shown to be shallow, allocthonous crustal slices trusted over intact continental blocks at lower crustal depths.

Such spectacular results resulted from surveys performed mostly in Europe, North America, Japan and Australia. Quite little modern seismic imagery has been performed in South America, Asia, Africa, and Antarctica, which remain terra incognita in terms of their deep crust and upper mantle structure. In Brazil, a pioneer geotectonic study was performed in the Tocantins Province, through the execution of three deep refraction seismic sections and teleseismic broadband methods. Results from those experiments, have decisively contributed to the understanding of the deep structure of Central Brazil and shed new light on the evolution of the Brasilia Belt and adjoining blocks.

The same research team from USP and UnB, together with researchers from Northeast Brazil universities (UFRN, UFPE, UFC) and from PETROBRAS, INPE, ON, UFOP, UNESP and UNICAMP, intend to use deep seismic imagery along two $100 \mathrm{~km}$ long profiles with 400 recording points, teleseismic data studies by using a dense network of broadband stations, together with gravity and magnetic data studies, as well as magnetotelluric sounding, to unravel the deep-crust structure of the Borborema Province, Northeastern Brazil, and with the participation of researchers of South Carolina and Cornell universities from USA.

The purpose of this presentation is to describe the processes involved in reaching the present stage of geotectonic studies in Brazil, to inform the present situation of the Borborema Province project, and analyze the next steps to conclude that project, apart from discussing which other regions of the Brazilian territory should be considered for future geotectonic studies.

\section{Main results from the Tocantins Province project}

Tocantins Province is a large Neoproterozoic Brasiliano orogen developed in central Brazil, following convergence of São Francisco/Congo, Paranapanema and Amazon cratons. The central sector of the province includes Araguaia Belt, bordering Amazon Craton, and Brasília Belt, at the western margin of São Francisco Craton. From west to east, Brasilia Belt comprises Neoproterozoic Goiás Magmatic Arc, Archean and Paleoproterozoic terrains of Goiás Massif, and a foreland fold-and-thrust belt.

During the last five years integrated geophysical studies, including deep seismic refraction experiments, receiver function studies, teleseismic tomography, gravimetric and high precision GPS surveys, were carried out in central Brazil (Berrocal et al., 1999, 2004; Soares et al., 2003; Assumpção et al., 2004a), aiming to improving knowledge of the lithospheric structure of Tocantins Province and bringing about new insights on its geological and tectonic evolution.

This work discusses the Central sector of Tocantins Province, comprised between latitudes $10^{\circ} \mathrm{S}-16^{\circ} \mathrm{S}$ and longitudes $45^{\circ} \mathrm{W}-51^{\circ} \mathrm{W}$ (Fig. 1). Although main focus of this 
work is the area crossed by the Porangatu (L1) and Cavalcante (L2) deep seismic refraction profiles, integration of seismic refraction data with available teleseismic seismo-logical results, gravimetric and aeromagnetic data provided data that allow to depicting traces of subduction of former oceanic lithosphere attached to Amazon Craton in central Brazil.

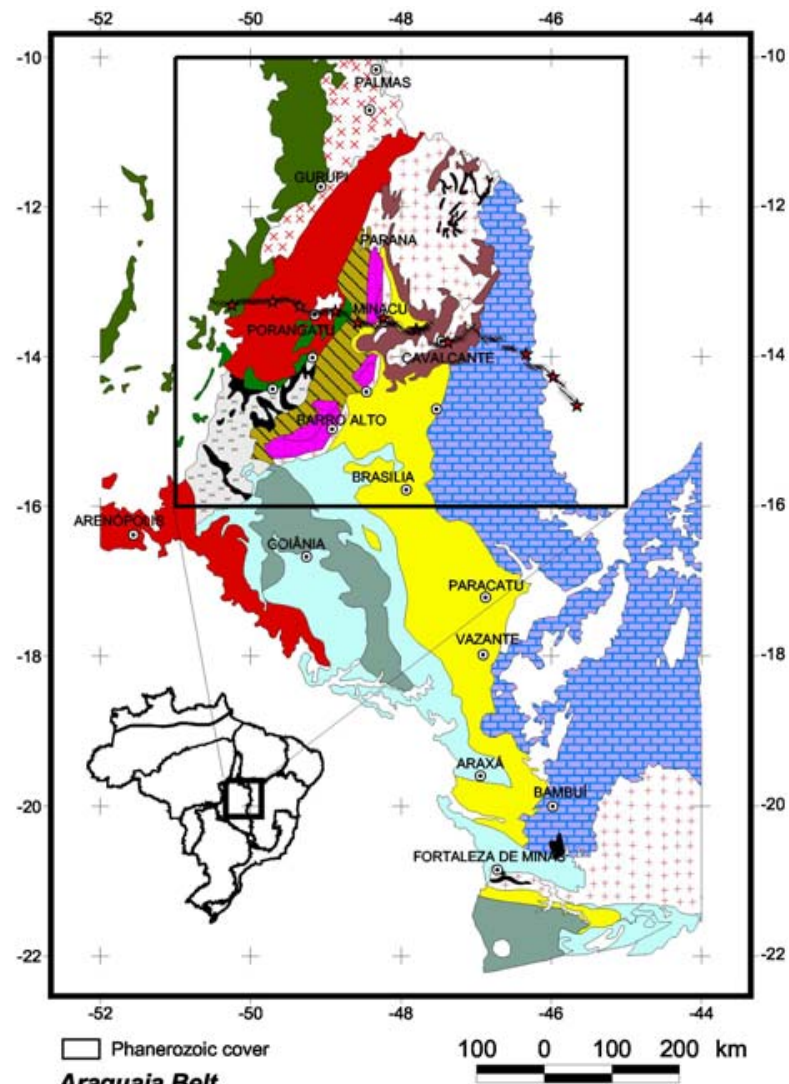

Araguaia Belt

\begin{tabular}{ll}
\hline Folded supracrustal rocks & Metamorphic core \\
Basement & Granulite / orthogneiss \\
\hline Brasília Belt & Foreland fold-and-thrust belt \\
Goiás Magmatic Arc & Passive margin sequence \\
Volcano-sedimentary sequences & Araxá and Andrelândia groups \\
Orthogneiss & Rift sequence (Arai Group) \\
Goid́s Massif & Orthogneiss / supracrustal belts \\
Metasedimentary cover & Sajo Francisco Craton \\
(Serra da Mesa Group) \\
$\begin{array}{l}\text { Layered complexes + } \\
\text { volcano-sedimentary sequences } \\
\text { Orthogneiss / greenstone belts }\end{array}$ \\
\hline
\end{tabular}

Figure 1. Geological map of Tocantins Province, showing the study area in the square enclosed in the figure. Porangatu and Cavalcante deep refraction lines are almost perpendicular to main geological trend. (Reference, Soares et al., 2006)

Porangatu and Cavalcante deep refraction experiments were deployed in northern Goiás in almost $530 \mathrm{~km}$ long WNW-ESE combined refraction lines with 120 recording points each, and a shot every $50 \mathrm{~km}$ along the lines making a total of 14 shots in both lines (Berrocal et al., 1999, 2004; Soares et al., 2003; 2005). IBEMUX emulsion explosive was used in this experiment filled in 6 inches boreholes $45 \mathrm{~m}$ to $65 \mathrm{~m}$ deep. The explosive charges varied from $500 \mathrm{~kg}$, in the center of the lines, to $1,000 \mathrm{~kg}$ in their extremes
Good quality of signals in the whole layout of L1 and L2 lines obtained in this project, permitted reliable peak up head and secondary phases ( $S$ waves and reflected phases). See seismic section on Fig. 2.

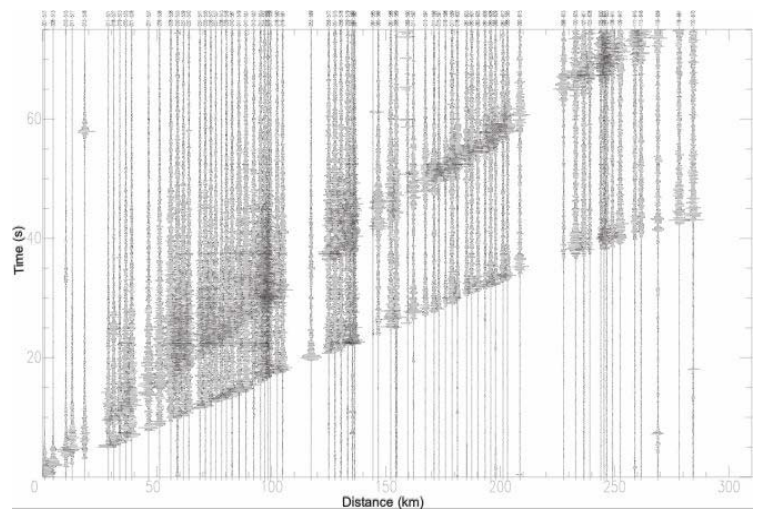

Figure 2. Seismic section of shot 1 in line L1 (shot EX11), showing the good quality data obtained in this experiment.

Preliminary analysis was performed with SU program and time readings were made through SAC software. TTInvers program was used to obtain 1D model between shots, although only considering horizontal layers, allowing estimation of travel-time curves for $S$ wave and distances for largest amplitude phases.

Two-dimensional models for refracted and reflected seismic phases were obtained with MacRay package. Although MacRay software is based on the same mathematical routines of SEIS program, its graphic interfaces allow the use of additional resources for modelling. Besides, MacRay permits simultaneous modelling with gravimetric and seismic data (Perosi, 2006).

In figures 3 is presented the reduced seismic sections, for $P$ waves, and in Fig 4 the ray tracing of $P$ and $S$ waves corresponding to L1 (Porangatu) shots EX11.

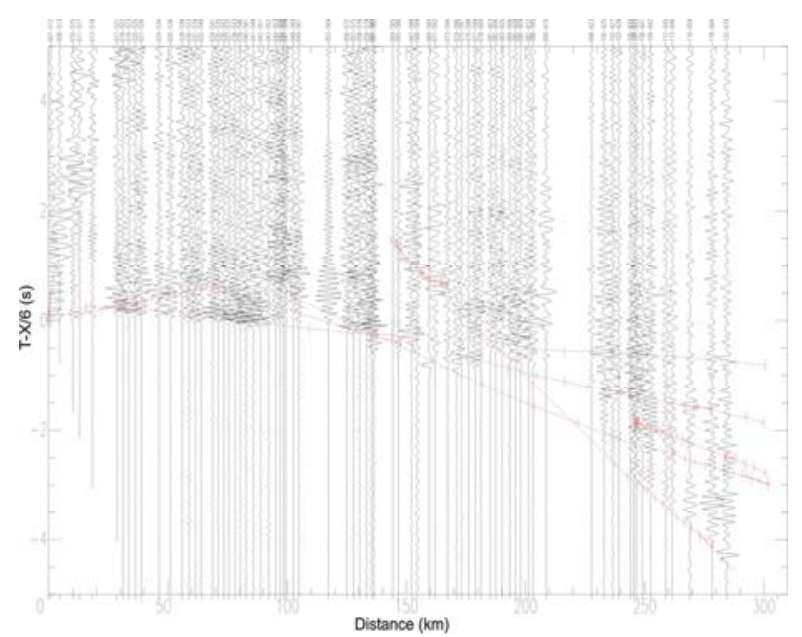

Figure 3. Reduced section of shot EX11 (Porangatu line, shot 1) showing several head and reflected waves, obtained in the 2D model shown below. 
a)

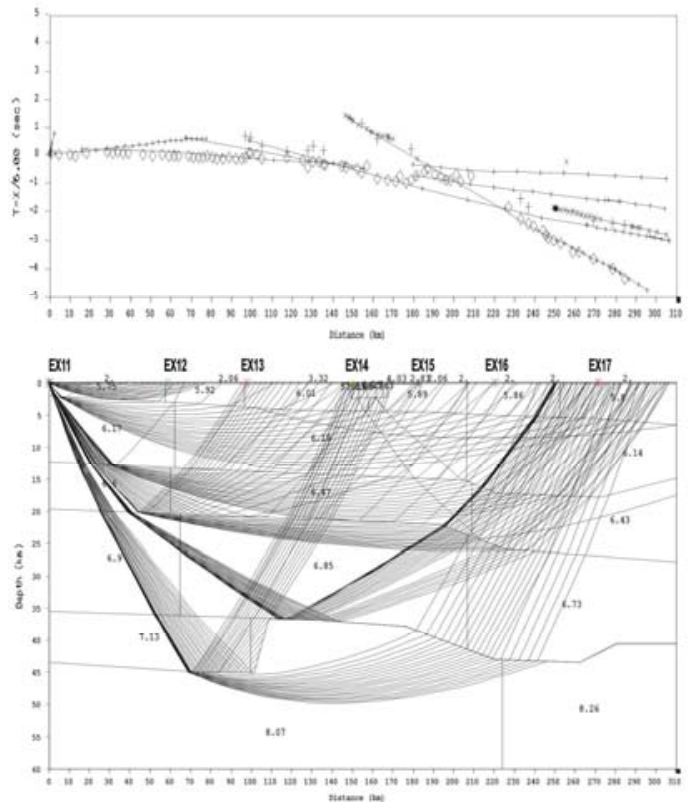

b)
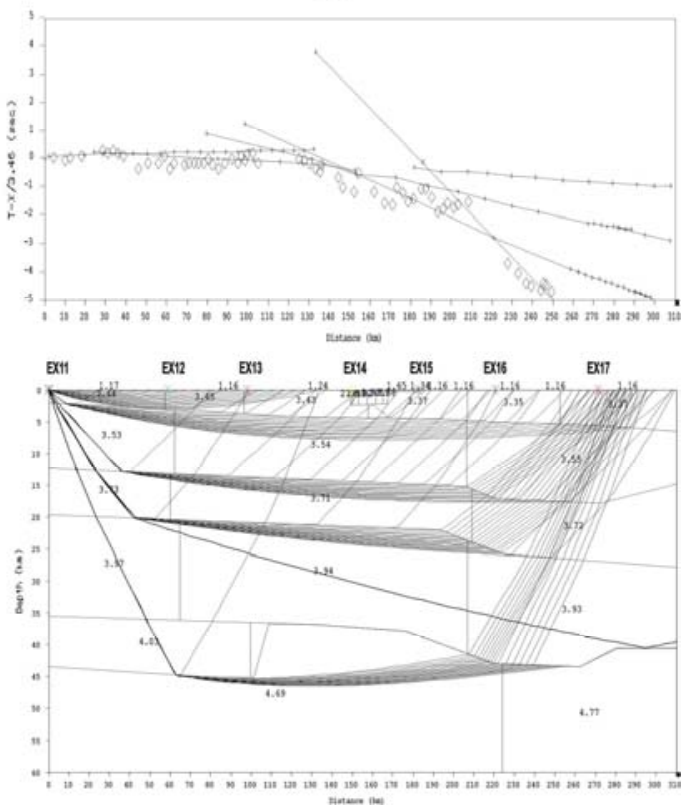

Figure 4. Ray tracing, below, and travel time curves, above, for $\mathrm{P}$ waves (a) and $\mathrm{S}$ waves (b), corresponding to refractions from the 2D model shown in Fig. 5. (Reference, Perosi, 2006)

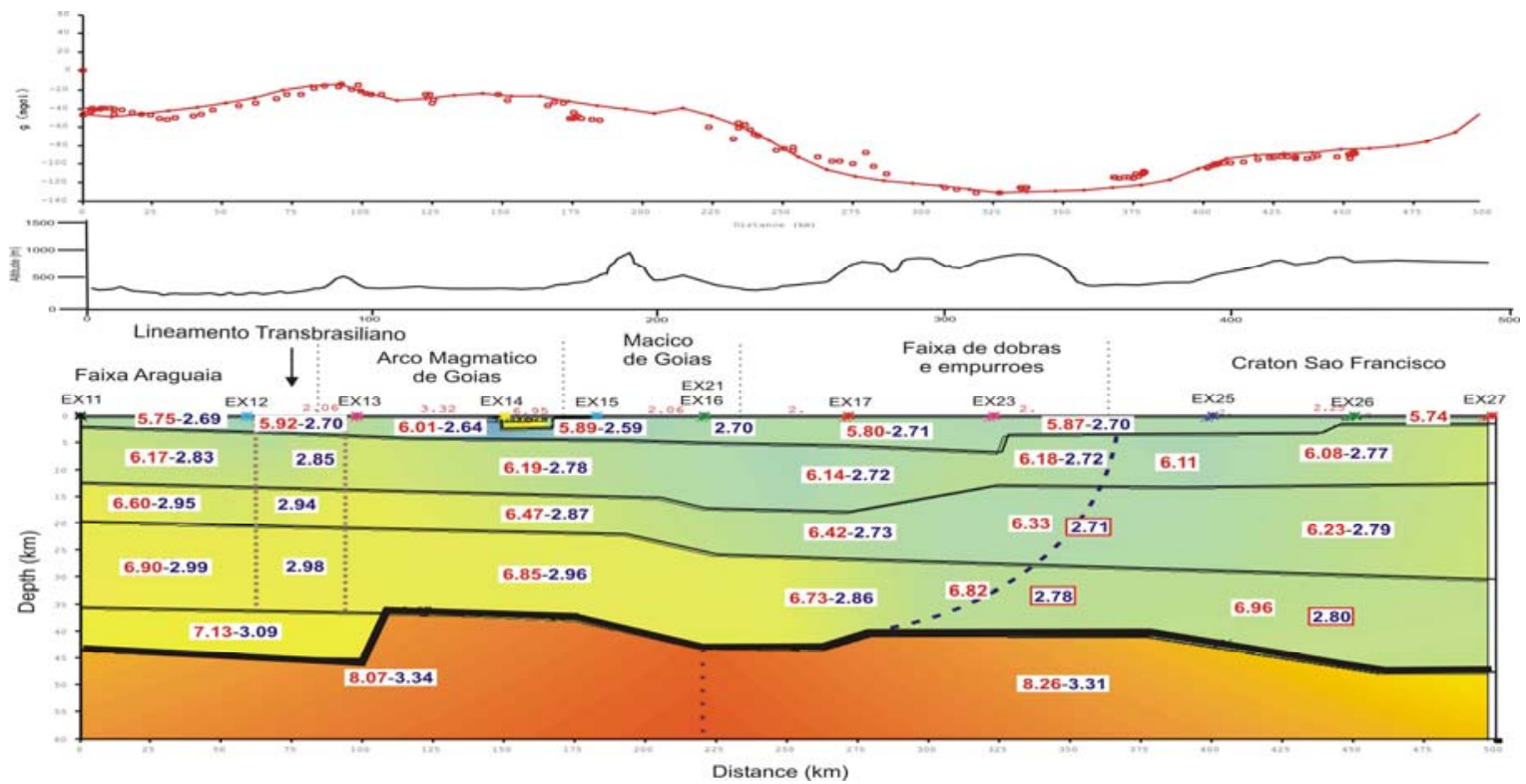

Figure 5. (Bottom) 2D seismic and gravimetric crustal model of Tocantins Province central portion, obtained from refraction lines L1 and L2; (middle) surface topography corresponding to the seismic refraction lines, and (top) theoretic and observed (circles) gravimetric data. (Reference, Perosi, 2006)

According to the model in Fig. 5, the upper crust in the study region is composed by two layers with $V_{P}$ less than $6.2 \mathrm{~km} / \mathrm{s}$ an no more than $15 \mathrm{~km}$ of depth. The middle crust is a relatively thin layer below the Tocantins units, little more than $5 \mathrm{~km}$, with $\mathrm{V}_{\mathrm{P}}$ around $6.5 \mathrm{~km} / \mathrm{s}$, and thicker below São Francisco Craton, around $15 \mathrm{~km}$ thick with $V_{P}$ just under $6.3 \mathrm{~km} / \mathrm{s}$. The lower crust is around $15 \mathrm{~km}$ thick beneath the Tocantins units, and thinner below the São Francisco craton, with a mean $V_{P}$ of $6.85 \mathrm{~km} / \mathrm{s}$.
A lower segment of lower crust $8 \mathrm{~km}$ thick with $V_{P} 7.1$ $\mathrm{km} / \mathrm{s}$, is present beneath the Araguaia Belt, which has been interpreted as a portion of the lower crust of the Amazon Craton (Soares et al., 2006), similar to the structure existent below the Pyrenees and Swiss Alps.

For modelling with gravimetric data was used the function $r=a+b V_{p}$ (Christensen \& Mooney, 1995), all theoretical values of density were taken inside the error calculated 
with the standard deviation given by those authors, except the values inside the read rectangles in the 2D model, in these cases the adopted values were larger than the permitted deviation. This seems to indicate the existence of a lateral discontinuity of crustal dimension.

Seismological studies with teleseismic data were recorder by several broadband portable stations, which allowed performing crustal and upper mantle structural studies using receiver function, tomography and surface wave's dispersion methods.

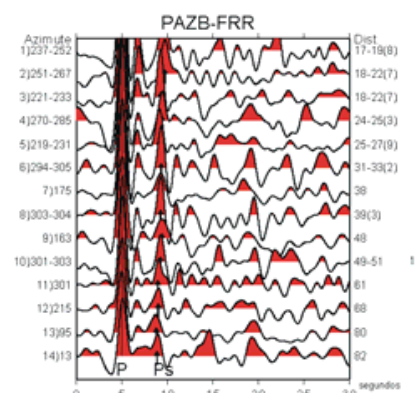

PORB.FRR
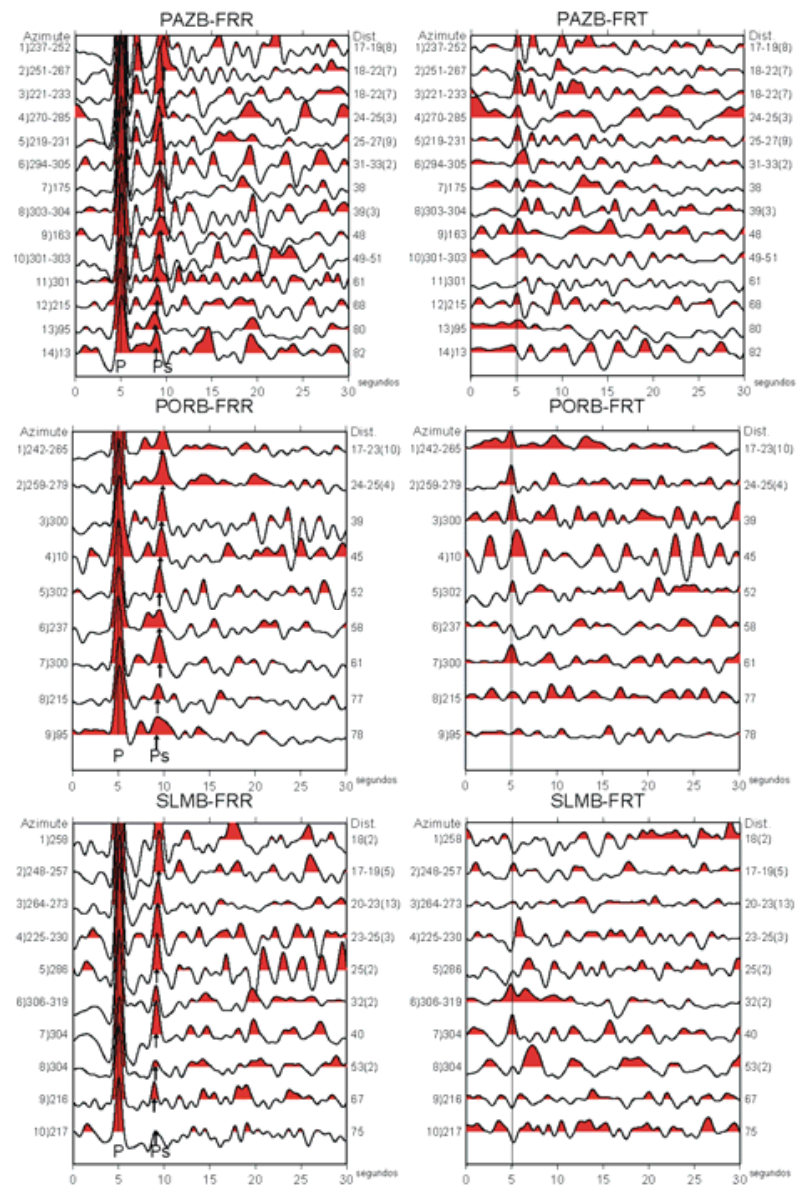

Figure 6. Examples of receiver functions obtained with data recorded at stations $\mathrm{PAZB}, \mathrm{PORB}$ and $\mathrm{SLMB}$, showing at the left the radial components and at the right, the transversal ones.

Several locals of the study region were occupied by those portable BB stations, which permitted to confirm the results obtained in the $2 \mathrm{D}$ refraction model in other areas of that region. Results like the ones shown in Fig. 6 were obtained during the Tocantins Province project permitting to construct a map like the one shown in Fig. 7.

Rayleigh and Love wave phase velocities were determided for the path between the stations PORB and PAZB, along the Magmatic Arc terrain (Assumpção et al., 2004a). Preliminary group velocities were determined by multi-filtering technique, which were used to isolate the fundamental modes that permitted the phase velocity calculation between both stations. An inversion by Ge- netic Algorithm for horizontal homogeneous plane layers was used to obtain the results presented by Assumpção et al. (2004a) that are in agreement with the 2D model from the refraction experiment.

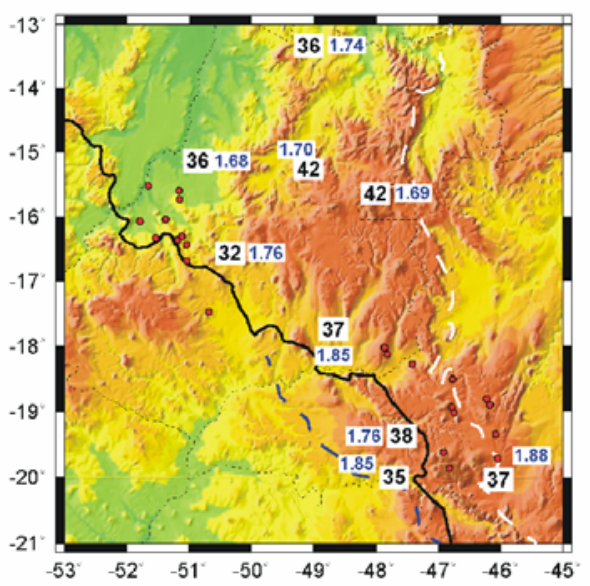

Figure 7. Central Brazil region showing the results of receiver function method: crustal depth and $V_{p} / V_{S}$ ratio. (França, 2003)

Travel time residuals of teleseismic $\mathrm{P}$ and $\mathrm{PKP}$ phases were inverted in an upper mantle tomographic study in Central Brazil (Assumpção et al., 2004). Relative residuals in this method are determined by waveform crosscorrelation. In addition to $\mathrm{P}$ wave anomalies, in a grid with spacing of 0.330 , the inversion included station correction and small epicentral dislocation. Smoothness constraints were used to regularize the inversion. An example of the results obtained with this method is shown in Fig. 8, which presents lateral P-wave velocity anomalies at $200 \mathrm{~km}$ of depth beneath Central Region of Brazil..

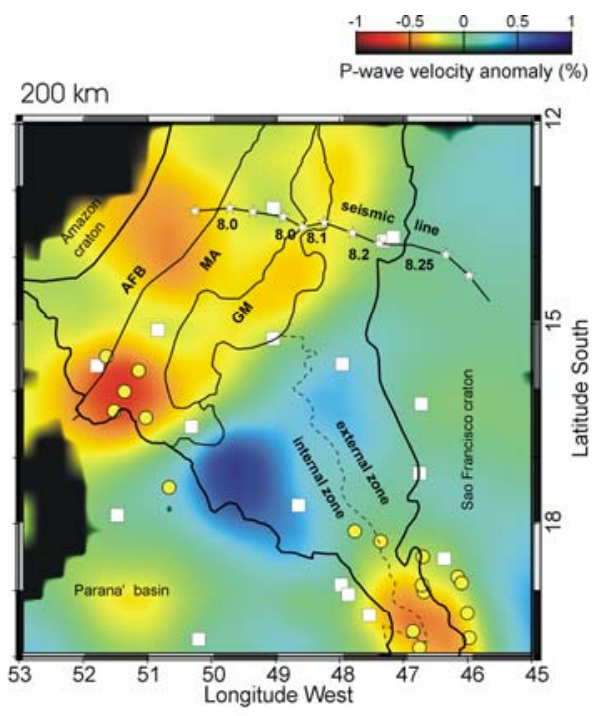

Figure 8. Result from a tomographic inversion in Central Brasil, showing lateral P-wave velocity anomalies at $200 \mathrm{~km}$ of depth. Observe the concordance between low $V_{P}$ anomaly (hot areas) and the existence of alkaline intrusions. 
The results obtained in Tocantins Province geotectonic project, which was supported by FAPESP, and curried out by geoscientists of IAG/USP and IG/UnB, have decisively contributed to the understanding of the deep structure of central Brazil and shed new light on the evolution of the Brasilia Belt and adjoining blocks. According to Soares et al. (2006b) those results provide evidence in depth of former São Francisco and Amazon plate subduction zones, suggesting at least one inversion in plate consumption in central Brazil tectonic history. Collage of Amazon Craton was the last convergent event and its related structures overprinted partially older ones. Geophysical data suggest Amazon plate subduction was from WNW to ESE.

\section{The Borborema Province Project}

The Borborema Province is located in the northeastern corner of the Brazilian territory and it is one of the most poorly understood regions of the South American continent, from the tectonic point of view. Part of the problem is that, due to the lack of detailed geophysical studies, little is known about its deep subsurface structure.

The Borborema Province $\left(-450.000 \mathrm{~km}^{2}\right)$ was originally defined as a large mosaic of fold belts, developed by tectonic, thermal, and magmatic events related to the Brasiliano Orogeny. This province is a complex framework of supracrustal fold-belts, separating more ancient, large crustal blocks of Paleoproterozoic age with small Archean nuclei, such as São Luiz Craton (a piece of West Africa Craton), Granja, Central Ceará, Orós, Rio Grande do Norte, Transversal Zone domain, PernambucoAlagoas, São Francisco Craton. These crustal blocks were amalgamated in the course of Brasiliano/PanAfrican Orogeny as part of Western Gondwana construction. In general, important shear zones whose signification is not clear mark those limits.

Considering older blocks have different geological properties, it is suggested some of them are suture zones. However, only in the Transbrasiliano Lineament case (or Sobral-Pedro II Shear Zone), there is some evidence it is actually a suture, besides the inference it will be the continuity of Kandi Lineament, identified as suture in Africa, separating West African Craton from Trans-Saharan terrains. In the other cases (Senador Pompeu, Portalegre, Patos, Pernambuco lineaments, among others) current controversies should be elucidated by deep seismic refraction or reflection.

Those large-scale structures cross over the region and delimit the fold belts and basement inliers, being covered at the west by Phanerozoic sediments of the Parnaiba basin, and to the north and east by the coastal MesoCenozoic deposits. Three geologically different domains can be delineated into the Province: the northern, transversal, and southern domains (Brito Neves et al. 2000). They are limited by the Patos and Pernambuco lineaments. Each domain may be divided into sub-domains, based on differences in their geology (see map in Fig. 9).

The same research team from IAG/USP and IG/UnB, that executed the geotectonic project in Tocantins Province, together with researchers from UFRN, UFPE, UFC,
UFOP, UNESP, UNICAMP, PETROBRAS, and INPE, presented in May 2005 to Millennium Institutions MCT/ CNPq program a proposal to curry on a geotectonic project in the Borborema Province, which was approved in November 2005. That project intends to perform deep seismic imagery along two almost $1000 \mathrm{~km}$ long profiles (Fig. 9 and 10) with at least 400 recording points, teleseismic data studies with 40 broadband temporary stations, gravity studies, and magnetotelluric studies that will be combined with geological studies including neotectonics, geochemistry, isotopic geology, structural geology and tectonics, to unravel the deep-crust structure of the Borborema Province.

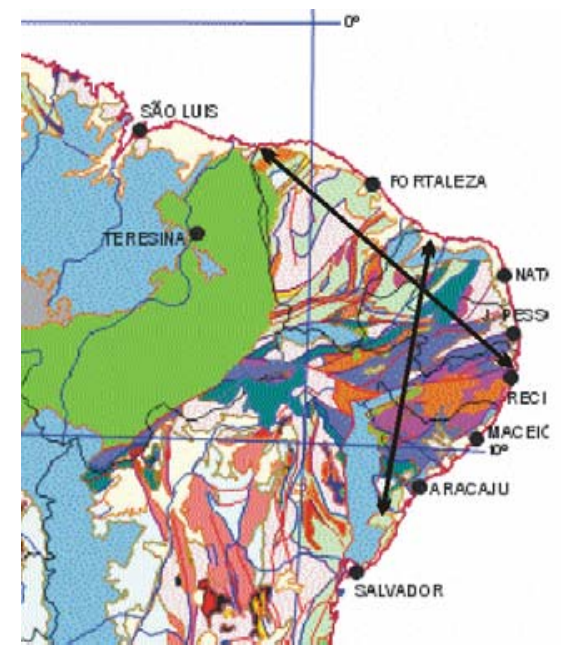

Figure 9. Geological map of Borborema Province showing the two proposed transects for deep seismic refraction experiements.

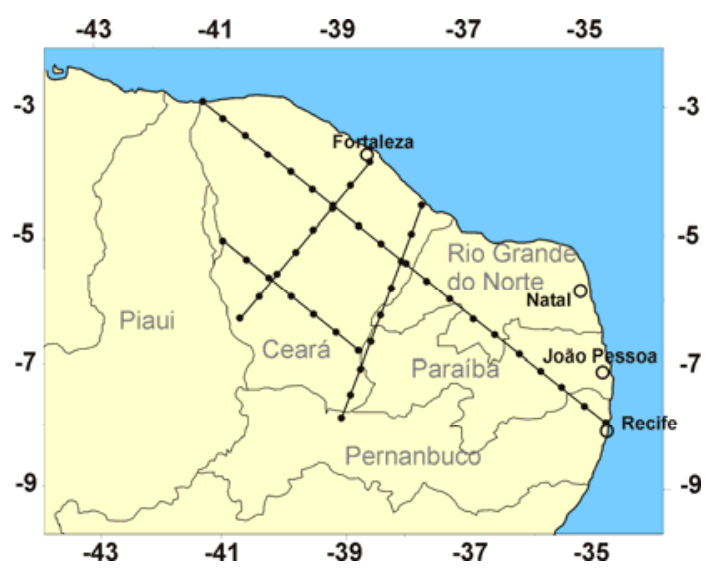

Figure 10. Interlinked refraction lines, a probable layout of refraction lines in the NW-SE transect in Borborema Province

For teleseismic data studies 40 broadband stations are being requested to the IRIS-PASSCAL program to record continuously in the Borborema Province for a period of about 2 years. The seismic stations will be evenly spread throughout the province and adjacent areas making up an overall array configuration of $\sim 1000 \mathrm{~km}$ of maximum aperture in the NS direction, $\sim 600 \mathrm{~km}$ in the EW direction, and an average spacing of $\sim 100 \mathrm{~km}$ between the stations. 
(see Fig. 11) The deployment configuration is especially suited for:

- Using array-based techniques to illuminate the upper mantle structures beneath the deployment, including differential travel-time tomography, improved surfacewave tomography, and receiver function migration methods

- Using single-station techniques to probe the crust and uppermost mantle beneath individual stations, including receiver function stacking method and the joint inversion of receiver functions and surface-wave dispersion.

- Using the SKS-splitting technique, which is also a single-station method, to investigate the signature of anisotropic structures beneath the stations.

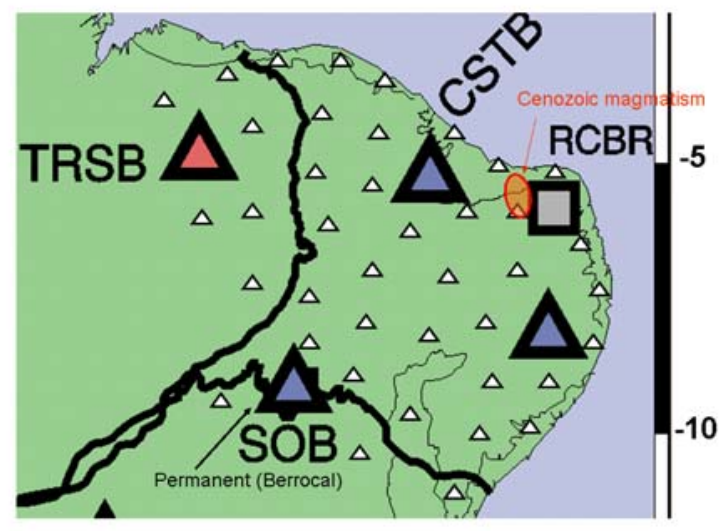

Figure 5 - Tentative locations of the PASSCAL broadband stations in the Borborema province experiment. Blue triangles are BLSP02 stations, red triangles are ETH stations and the square is the permanent station RCBR.

It is worth mentioning that most of the regional events originating deep in the Andean subduction zone can be employed to compute receiver functions. These events are less attenuated due to a shorter ray-path and can add high frequency information, and thus more detail, to the receiver function techniques mentioned.

The tomographic and migrated images will be critical for linking intriguing surface geological observations with deep subsurface processes. We are interested, for instance, in understanding the presence of intraplate Cenozoic magmatism in the region -which is Neoproterozoic in age- or the origin of the major geoid anomaly (+10 m) that might be driving its seismic and neotectonic activity. The crustal probes, on the other hand, will provide $V_{\mathrm{P}} / \mathrm{V}_{\mathrm{S}}$ ratio estimates, crustal thicknesses, and detailed S-wave velocity models for the crust and uppermost mantle that will, at the very least, contribute to an ongoing debate about the role of mafic underplating during Precambrian crustal evolution.

Given the high demand of PASSCAL broadband equipment, we expect a delay of at least 1.5 to 2 years to be available for the Borborema project. For this reason, it was created a preliminary stage using an array with a smaller number of BB stations, 6 of them with new equipment being bought with the Millennium founds, another 6 with BB equipment belonging to IAG/USP projects, and from the permanent station RCBR.

The goal of this preliminary stage is to obtain first-pass model of the subsurface geology of the Borborema Province while waiting for the availability of PASSCAL equipment. The results will provide a fast complement to the two geophysical transect, including the deep seismic refraction experiments, which equipment is leas required than the BB seismographs, and could be available earlier.

\section{Future geotectonic studies in Brazil}

Another possible source of seismographic equipment that may be available to be used in the Borborema project, is the Rede de Estudos Geotectônicos recently created by Petrobras. This represents the future of geotectonic studies in Brazil.

\section{Referências}

Assumpção, M., An, M., Bianchi, M., França, G., Rocha, M., Barbosa, J.R. and Berrocal, J., Seismic studies of the Brasília Fold Belt at the western border of the São Francisco Craton, central Brazil, using receiver function, surface wave dispersion, and teleseismic tomography, Tectonophysics, 388, 173-185, 2004.

Berrocal, J., Assumpção, M., Côgo de Sá, N., Marangoni, Y., Fuck, R. A., Pimentel, M. and D`el-Rey Silva, L.J.H., Linhas de refração sísmica profunda, First annual report of the thematic project "Estudos Geofísicos e Modelo Tectônico dos Setores Central e Sudeste da Província Tocantins, Brasil Central", supported by FAPESP, 1999.

Berrocal, J., Marangoni, Y., Côgo de Sá, N., Fuck, R.A., Soares, J.E.P., Dantas, E., Perosi, F., and Fernandes, C., Deep seismic refraction and gravity crustal model and tectonic deformation in Tocantins Province, Central Brazil. Tectonophysics, 388, 187199, 2004.

Brito Neves, B.B., Santos, E.J. \& Van Schmus, W.R. Tectonic history of the Borborema Province northeastern Brazil. In Cordani, U.G., Milani, E.J., Thomas Filho, A., Campos, D.A. (Editors) Tectonic Evolution of South America, Rio de Janeiro31 Internaional Geological Congress, p 151-182, 2000

Christensen, N.I. \& Mooney, W.D., Seismic velocity structure and composition of the continental crust: a global view. J. Geophys. Res., v 100 (B7): 9761-9788. 1995.

França, G.S.L.A., Estrutura da crosta no Sudeste e Centro-Oeste do Brasil, usando função do receptor, PhD Thesis, IAG/USP, 2003.

Perosi, F. Estrutura Crustal do setor central da Província Tocantins utilizando ondas $\mathrm{P}, \mathrm{S}$ e fases refletidas com dados de refração sísmica profunda. PhD Thesis, IAG/USP, 2006.

Soares, J.E., Berrocal, J. and Fuck, R. Seismic crustal structure in central Brazil. 8th Internat. Cong. of the Brazilian Geophy. Soc., Rio de Janeiro. Expanded Abstract Volume. 2003.

Soares, J.E.P., Berrocal, J., Fuck, R.A. and Ventura, D. (2006a). Seismic characteristics of central Brazil crust and upper mantle:a deep seismic refraction study, submitted to Journal of Geophysics Research in April, 2006.

Soares, J.E., Fuck, R.A., Berrocal, J. and Vilhena, R.M., Geophysical evidence of Amazon subduction in central Brazil: a new insight into Tocantins Province evolution, submitted to Tectonophysics in April/2005. 